\title{
Radio Daze
}

Henry B. Balfanz, Alma College, USA

\begin{abstract}
Radio has been a part of the American advertising landscape since the 1920s. Many threats to the industry have been thwarted by the strength and effectiveness of the medium. Prior to the deregulation of the industry in the 1990s and the technological change of the $21^{\text {st }}$ century, there were literally hundreds of small entrepreneurs, owning one or two stations, spread across the country. This is the mythical story of Gus Rowekamp, who owns two stations in a midsize Midwestern market. He hangs on as an owner/operator, putting most of his focus on the efforts of his advertising sales staff.
\end{abstract}

Keywords: Radio; Advertising; Sales; Deregulation; Technological Change

Suggested Courses: Selling; Sales Management; Radio; Entrepreneurship

\section{INTRODUCTION}

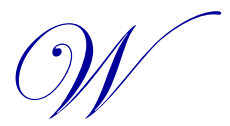

RIL and WWST are two radio stations owned by Gus Rowekamp in the metropolitan area of Beeson, Illinois, an area with a population of about 100,000. The radio business has changed greatly in the last twenty years, and most in the industry would consider Rowekamp's operation to be stuck 'in the good old days'. Not only in the sense of the programming on each station, but in terms of the fact he only owns two stations in a market where he could own up to six signals (4 FM and 2 AM).

The radio industry changed in the early 1990s when the Federal Communications Commission altered its regulations on station ownership (Democracy in Peril, http://www.truth-out.org/news/item/34789-democracy-in-peril-twentyyears-of-media-consolidation-under-the-telecommunications-act) Previous to the change, a radio entrepreneur could only own one AM and one FM station in each market.

And of course, the digital revolution of the $21^{\text {st }}$ century has changed the media and advertising business in a big way, cutting into advertising budgets that previously went to radio stations and other traditional media. Yet, consolidation of radio station ownership and the advent of digital technology has cut personnel expenses back greatly, still making media ownership a viable business.

Despite the media and advertising environment changes, Rowekamp has managed to hang on, operating an 'Oldies' station and a 'Talk' station. WRIL-AM features Talk around the clock, featuring a local talk show in the morning hours (5-10 am), and syndicated national talk hosts the rest of the day. The station also does the play-by-play of local high school sports and during the baseball season carries the Chicago Cubs play-by-play. The station calls itself "We're Talkin' 1280". Most talk stations, with the exception of the sports audience, tend to target Adults 55 and older. The FM station, WWST, is an oldies station featuring hits from the rock and roll era of the $60 \mathrm{~s}$ and $70 \mathrm{~s}$. Most songs are upbeat and range from the Beach Boys to Deep Purple. WWST is known as 'Great Oldies 105'. Similar to the AM station, WWST targets an Adult 50 and older audience.

\section{HOW RADIO STATIONS MAKE MONEY}

Rowekamp's operations sell advertising, with about $85 \%$ of the advertising on the FM station sold to local businesses. On the AM station, about $95 \%$ of the advertising is local. The remaining percentage of the sold advertising time is sold to national advertisers who work with firms in larger cities. For example, the local Target store advertising comes out of an advertising agency in Minneapolis through the national rep firm hired by Rowekamp to represent his stations. 
Needless to say, national advertising is a very small part of the revenue. Rowekamp relies on local advertising for survival. It is an absolute necessity.

\section{THE SALES STAFF OF WRIL AND WWST}

Joe Berry is the local advertising sales manager for WRIL and WWST. He has a staff of about five salespeople, with three very competent advertising executives and two positions in which he experiences a lot of turnover. The average tenure of his three competent reps is ten years; with his remaining two positions, about one year.

All salespeople on the WRIL/WWST staff can sell advertising on both stations. The three veteran salespeople are compensated on a "draw against commission at a $15 \%$ commission rate compensation plan." This means they are given an advance (or draw) of $\$ 1,500.00$ per month. They must sell at least $\$ 10,000$ in that month they receive the draw. They are then compensated for all sales past the \$10,000 level. For instance, veteran Sally Smith billed \$20,000 in April. At a $15 \%$ commission rate, she makes $\$ 3,000$ in that month. She has been advanced $\$ 1,500$ already, so in May she receives an additional $\$ 1,500$ commission check for April sales.

The three veterans range in yearly income from $\$ 50,000$ to $\$ 70,000$. Reaching their monthly draw (for these three vets) is never an issue.

The two newer salespeople are compensated with a $\$ 2,000$ salary each month for their first year. They are given sales and activity goals by Joe Berry each month and expected to reach them. Very seldom in that first six months will a newer salesperson sell enough advertising in a month to cover their salary at the commission rate of $15 \%$. It is hoped by the end of the year, at the latest, the newer salesperson will earn more than the $\$ 2,000$ salary each month so making the transition to the draw against commission plan smoothly. At any rate, at the end of year one, the newer salesperson is switched to the $15 \%$ draw against commission compensation plan. Often a newer salesperson will quit at this point, as he or she is frustrated and believes they won't succeed.

Berry also handles about a dozen local accounts himself. They are among the radio stations' larger accounts, including local banks, local car dealers, and the nearby mall. His main responsibility, however, is the management of the sales staff. Berry is compensated on a small 5\% commission for the accounts he handles himself plus an override of $3 \%$ on total local sales and is given a salary that may increase from year to year based on previous year's performance. Last year, Berry earned $\$ 98,000$ in gross income.

The fact that he handles some accounts of his own and is compensated for them generates some controversy among his sales staff. They feel he has kept the best (higher billing) accounts for himself. They feel he needs to give those accounts to the sales staff.

\section{COMPETITORS}

There are eight other radio stations in the Beeson, IL market; two groups of four stations operated by two of the larger media groups in the country. One of these firms owns 1,100 stations nationwide while the other owns 800 . Both groups approach Rowekamp at least twice a year with offers to buy his stations to combine with their forces. Both groups operate in their markets very lean (in terms of personnel and promotion) and would be even more profitable if they could add Rowekamp's stations. They would lower the expenses that Rowekamp incurs by eliminating Rowekamp's and possibly Berry's salary, the office staff, consolidating into one building, engineering expenses, eliminating announcers, etc. They would also, hopefully, be able to increase advertising revenue. In addition, in the market, there is a local TV station, a local cable operation, and a daily newspaper; in addition to Facebook and a multitude of other digital competitors.

Rowekamp always turns down the offers, figuring at some point they'll raise their offers to an astronomical level. He is frustrated, however, with the lack of sales growth for his two stations, and he's not sure his sales effort is as managed as well as it could be. 


\section{MARKET SHARE}

An examination of the revenue, direct expenses, and the related market share (Appendix A) tells Rowekamp he needs to be concerned, as both local and national revenue have dropped from three years ago. He's also concerned that his direct expenses have increased (on a \% basis).

The market share report shows some alarming numbers for the entire marketplace as well. Local sales for the entire market dropped approximately $\$ 600,000$ in the last three years. As well, his stations' local market share has dropped from $17.2 \%$ to $16.2 \%$, dropping his local sales by nearly $\$ 200,000$.

If the market revenue continues to shrink, and his stations' market share continues to decline, Rowekamp will be in a position where he'll have to cut expenses to continue to show a profit. Or, as he thinks over on a daily basis, maybe it's time to sell and finally retire?

\section{ROWEKAMP'S ANALYSIS}

Rowekamp believes his treatment of his sales manager has been more than fair. He raised his salary two years ago as Berry had a job offer from one of the market competitors and threatened to leave. As he raised his salary, he also had Berry sign a non-compete agreement, meaning he could not go to work for a local competitor if he quit working for Rowekamp. Obviously, now it appears he has rewarded his sales manager for a poor performance. Has Berry become complacent, he asks himself, or is the market shrinkage simply having a bigger effect on us than I thought? In either case, action on Rowekamp's part is called for.

He talks to Berry on a daily basis, attempting to motivate the sales manager. Berry often perceives the conversational tone to be aggravating, not motivating:

Rowekamp: You've seen the numbers and know our issues, just like me. Is there any way we can get more sales out of our two newest salespeople?

Berry: I don't know, they are always complaining that all the good accounts are already taken.

Rowekamp: You know that's not true. The 'good' accounts haven't been advertising with us forever. It took effort on somebody's part to sell them. Maybe you could spend more time training them and building their confidence?

Berry: I don't think I really have the time and I'm not sure they'll listen. I don't know what the answer is.

Another conversation on a different day, discussing the three veteran salespeople.

Rowekamp: Are you sure they're working as hard as they could? When was the last time any one of them called on a new account?

Berry: I told them not to worry about new accounts. They are making enough already. I don't think its fair for them to call on new accounts while we have two salespeople who are struggling!

Yet another conversation regarding the competition:

Rowekamp: We used to get $\$ 10,000$ a year out of Beeson Chevrolet. Now we don't get a dime!! I hear them on that country station all the time!

Berry: Their rates are a lot lower than ours. I know you don't like to lower rates, but if I match the low price the country station is giving them, I'm sure we could get some of the business. 


\section{"RADIO IS NOT A COMMODITY."}

Rowekamp has always focused on making sure his prices per commercial are among the highest in the marketplace. Advertisers will always negotiate price, but he's always been able to charge a premium for his radio station advertising because he's invested in his on-air sound, that is, focused not only on music but also providing a lot of local news and information, as well as local sports. He is frustrated not only by the advertisers who tend to dismiss the investments he's made in his operation, but he's also frustrated by his sales manager and salespeople who seemingly believe the only way to sell is by 'lowering the price'.

"Every time a sales call is made, a sale is made. Either we sell them advertising at our price, or they sell us on lowering the price," Rowekamp laments. "Radio is not a commodity; yet that's what we're being forced into being."

When describing a commodity, Rowekamp will use the example of sweet corn. "If farmer A grows sweet corn and sells it for 10 cents an ear, and farmer B grows sweet corn and sells it for 5 cents an ear, the average customer will buy her sweet corn from farmer B because it's cheaper. There are no distinctions, other than price, between the sweet corn farmer A sells and the sweet corn farmer B sells."

"We have one customer who openly tells me, 'radio is all the same'. That's why he buys the cheapest price he can find," laments Rowekamp. Obviously, Rowekamp disagrees with that decision.

\section{RATINGS}

The Beeson, IL market radio listenership is surveyed once a year by Nielsen Audio Ratings. Nielsen purchased the long time rating service Arbitron in 2013. (Nielsen.com, http://www.nielsen.com/us/en/press-room/2013/nielsenacquires-arbitron.html). However, none of the radio stations in the market, including Rowekamp's, subscribe to the rating service or any other rating service, believing the cost is too high for the size of the market. Therefore, they cannot quote the ratings information to advertisers.

\section{ADVERTISING OPTIONS AND HOURLY LIMIT}

WRIL/WWST offers some advertising options for local advertisers, but perhaps not as many as the stations' competitors tend to offer. Its Rowekamp's belief that the :60 second commercial is the length option that is most effective for his advertisers. He knows the other stations really emphasize the use of :30 commercials instead of :60. At Rowekamps's stations, his :30 commercials are $80 \%$ of the price of the :60. Competitors tend to only charge $50 \%$ of their own :60 rate. He also limits the number of commercials per hour on both of his stations to 12 units an hour, no matter how the long the commercial.

In other words, WWST may run 12-:30 commercials per hour or 12-:60 commercials per hour, or some combination thereof as long as its limited to a max of twelve commercials. Some believe Rowekamp's only motivation for believing in the effectiveness of :60 ads is because he can charge more. His sales manager and salespeople openly express frustration with the pricing policy and the commercial limit policy.

The stations also make available three hour remote broadcasts on each station. For example, a new health club may have an open house. A WWST announcer will do four live breaks for three hours from the open house. Breaks are slated to be :60 in length, but generally last more than two minutes, as the remote announcer gets carried away singing the praises of the advertiser. ("I'm going to buy the deejay an egg timer," complains Rowekamp). WWST will park its late model broadcast van outside the health club, attempting to draw attention to the broadcast event.

Advertisers can also buy sponsorships of the high school and Chicago Cubs play-by-play on WRIL. As these are exclusives in the marketplace, WRIL can charge a premium price for these commercials. 


\section{WHAT DO THE ADVERTISERS THINK?}

WRIL/WWST are well-established advertising media in the marketplace. Gus Rowekamp is respected by the local business community as he has a good reputation for being a real cheerleader for the community and treating his customers right.

Moreover, his Sales Manager Joe Berry and the three long time experienced advertising salespeople have been successful in building a lot of confidence in the stations by the businesspeople. Some advertisers are concerned, however, that there seems to be a lot of turnover for the remaining two sales positions and fear the stations are losing their respect in the marketplace because of the changes.

"Just about the time I get to know my sales rep, they send in a new one," one restauranteur told his next door neighbor.

\section{AUTHOR BIOGRAPHY}

Henry Balfanz is an Assistant Professor of Business Administration at Alma College in Alma, Michigan. Balfanz also taught Marketing at Bradley University in Peoria, Illinois and Northern Michigan University in Marquette, Michigan. He has also taught at Vysoka Skola Ekonomicka in Prague, Czech Republic on seven occasions. Prior to teaching, Balfanz was an Executive in the broadcast, newspaper, and advertising industries. Balfanz holds a Bachelor of Science in Broadcast Management from Southern Illinois University at Carbondale and a Masters of Business Administration from Bradley University. E-mail: Balfanzhb@alma.edu.

\section{REFERENCES}

Corcoran, M. (2016). Democracy in peril, Retrieved from truthout.org, http://www.truth-out.org/news/item/34789-democracy-inperil-twenty-years-of-media-consolidation-under-the-telecommunications-act

Nielsen.com (2013). http://www.nielsen.com/us/en/press-room/2013/nielsen-acquires-arbitron.html.

\section{SUGGESTED READING}

Abel, J. (2015). The storytelling secrets. Crown Publishing. Geller, V. (2006, 2012) Beyond powerful radio. Focal Press.

Lill, D. J., \& Lill, J. K. (2016). Selling: The profession. DM Bass Publications.

MacFarland, D. T. (1997). Future radio programming strategies in digital age. Erlbaum Associates Publishing.

Nielsen.com (2013). http://www.nielsen.com/us/en/press-room/2013/nielsen-acquires-arbitron.html.

O’Guinn, T., Allen, C., Semenik, R. J., \& Close Scheinbaum, A. (2015). Advertising and integrated brand promotion. Cengage Learning.

Ries, A., \& Trout, J. (1981, 2001). Positioning: The battle for your mind. McGraw Hill.

Schiffman, S. (1994). The 25 sales habits of highly successful salespeople. Adams Media Corporation. 
APPENDIX A

\begin{tabular}{|c|c|c|c|}
\hline WRIL/WWST & Three Years Ago & Two Years Ago & Last Year \\
\hline \multicolumn{4}{|l|}{ Income } \\
\hline Local Sales & $\$ 1,765,000$ & $\$ 1,651,000$ & $\$ 1,567,821$ \\
\hline National Sales & $\$ 302,000$ & $\$ 298,000$ & $\$ 295,400$ \\
\hline Gross Sales Total & $\$ 2,067,000$ & $\$ 1,949,000$ & $\$ 1,863,221$ \\
\hline \multicolumn{4}{|l|}{ Direct Expenses } \\
\hline Local Sales Commision & $\$ 215,400$ & $\$ 181,610$ & $\$ 178,000$ \\
\hline Local Sales Manager Comp. & $\$ 91,000$ & $\$ 92,000$ & $\$ 98,167$ \\
\hline Local Sales Salary & $\$ 48,000$ & $\$ 48,000$ & $\$ 48,000$ \\
\hline National Sales Commission & $\$ 83,805$ & $\$ 82,695$ & $\$ 81,973$ \\
\hline Direct Expenses Total & $\$ 438,205$ & $\$ 404,305$ & $\$ 406,140$ \\
\hline Net Sales & $\$ 1,628,795$ & $\$ 1,544,695$ & $\$ 1,457,081$ \\
\hline \multicolumn{4}{|l|}{ Market Share Wril/ Wwst } \\
\hline Local Sales & $17.2 \%$ & $18.2 \%$ & $16.2 \%$ \\
\hline National Sales & $20.1 \%$ & $21 \%$ & $24.1 \%$ \\
\hline Total Market Sales & Three Years Ago & Two Years Ago & Last Year \\
\hline Local Sales & $\$ 10,262,000$ & $\$ 9,071,429$ & $\$ 9,678,907$ \\
\hline National Sales & $\$ 1,502,488$ & $\$ 1,419,047$ & $\$ 1,225,726$ \\
\hline
\end{tabular}

\section{Questions for Discussion}

1) How are Rowekamp's stations positioned in the marketplace? Should he consider format changes to target a different audience? Why or why not?

2) Since Berry is having trouble keeping a $4^{\text {th }}$ and $5^{\text {th }}$ salesperson, should he suggest to Rowekamp that the sales staff be cut back to three? If not, how can he improve their performance and make them more productive?

3) What are the advantages of a commission based compensation plan for the sales staff? For the ownership? What are the disadvantages for each?

4) If you were the owner, would you change Berry's compensation plan? If so, how? If not, why not?

5) Why do some advertisers consider radio to be a commodity? How would you respond to that opinion?

6) Rowekamp seems set in his ways about selling primarily :60 commercials, despite his competitors pushing :30 commercials. Should he stand by his belief in what's most effective?

7) Rowekamp also limits a maximum of twelve commercials per hour. Is this a smart strategy? What are the advantages and the drawbacks?

8) Would purchasing the right to use the ratings (assuming his stations are rated favorably) to assist in his sales efforts a good move? Why or why not?

9) Should Rowekamp sell his stations to one of his competitors and retire? Why or why not?

Teaching notes provided upon request. 